Esta revista forma parte del acervo de la Biblioteca Jurídica Virtual del Instituto de Investigaciones Jurídicas de la UNAM http://www.juridicas.unam.mx

https://biblio.juridicas.unam.mx

https://revistas.juridicas.unam.mx

DOI: http://dx.doi.org/10.22201/iij.24484873e.2020.158.15627

\title{
ARTÍGULOS
}

Universidad Nacional Autónoma de México, IIJ-BJV, 2020

https://revistas.juridicas.unam.mx/index.php/derecho-comparado/issue/archive 


\title{
CALAMIDADES DEL DEREGHO (POST)COLONIAL Y SU ORIENTALISMO: RELIGIÓN, IDENTIDAD Y LIBERTAD INDIVIDUAL EN EGIPTO, IRAQ Y TÚNEZ*
}

\author{
CALAMITIES OF THE (POST) COLONIAL LAW AND IT'S \\ ORIENTALISM: RELIGIOUS AFFILIATION AND INDIVIDUAL \\ LIBERTY IN EGYPT, IRAQ AND TUNISIA
}

\section{Samer ALNASIR**}

RESUMEN: El principio constitucional español plasmado en el artículo 16.2 de la Constitución Española de 1978, referido a la prohibición de declarar sobre la propia ideología, religión o creencia no tiene cabida en muchos otros sistemas jurídicos. La pertenencia ideológica forma parte del esquema de filiación civil, además de la filiación étnica o política, constituyendo un parámetro de identidad civil, y por ende determinante del fuero jurídico aplicable. Tanto en los casos de Iraq y Egipto como en otros, sus leyes no sólo exigen declarar sobre la etnia y la religión, sino que consignan para ello un asiento específico en el registro
ABSTRACT: The constitutional principle introduced in article 16.2 of the Spanish Constitution of 1978, which forbids compelling one to declare their own religion, ideology, or beliefs, does not exist in other legal systems, as religious and ethnic belonging is considered to be part of the civil and/or national identity. In cases such as Iraq and Egypt, the law not only requires the declaration of personal religious affiliation but also records it in the civil register along with additional information on ethnicity and religious schools of thought. This officially registered information is a condition for the exercise of other civil liberties. This article analyzes this issue by focusing on several case law studies from such countries. It should be noted that many of these legal

* Recibido el 30 de enero de 2020; aprobado el 16 de noviembre de 2020.

Tomo la idea de las calamidades del derecho del maestro Garzón Valdés (2004). El presente trabajo se ciñe en la misma línea conceptual, acusando, en este caso, y calificando la aberración intelectual de las secuelas del orientalismo despótico-colonial que instrumentalizó el derecho, y por ende la cognición y la identidad de los pueblos, a su propio servicio.

** ORCID: 0000-0002-9232-9035. Profesor Asociado en Historia del Derecho UC3M. Doctorando en Filosofía Ética y Política en la UNED. Máster en Protocolo UNED. Máster en Derecho Público UC3M. Máster en Filosofía del Derecho AETD y DEA en Derecho administrativo CEU. Ex. Miembro de la comisión constituyente de Iraq. Ex. Asesor de la Corte Penal especial de Iraq. Correo electrónico: samer@alnasirorg.

Agradezco infinitamente al tanto apoyo a la investigación de origen de la que procede este artículo al Profesor Tomás de la Quadra Salcedo y Fernández del Castillo, Catedrático Emérito de la UC3M; y al Profesor Francisco Colom González, titular de investigación

Boletín Mexicano de Derecho Comparado, nueva serie, año LIII, núm. 158, mayo-agosto de 2020, pp. 485-519.

Esta obra está bajo una Licencia Creative Commons Atribución-NoComercial-SinDerivar 4.0 Internacional, IIJ-UNAM. 
civil y las cédulas de identificación. Estos casos encierran un sinfín de problemas para el ejercicio de muchos otros derechos que el presente estudio tratará de abordar analizando de la praxis judicial y administrativa en los tribunales, una praxis que, habiendo sido prohibida en Europa, fue sembrada e impuesta en otros lugares por los propios colonizadores europeos, dejando a las antiguas colonias en un laberinto de segregación y sectarismo. Así, y mediante un análisis empírico, se intentará poner en evidencia el doloroso dilema que atraviesan a las sociedades fisuradas y lastradas aún por las secuelas impuestas por el colonialismo bajo el pretexto de la protección de las minorías postulado por occidente.

Palabras claves: libertad religiosa, calamidades del derecho, orientalismo, identidad, minorías, derecho punzante. practices are residuals from European colonialism; while these practices were forbidden in Europe, they were often implemented in the colonies. Using empirical references, this article highlights this issue that still haunts many post-colonial societies under the old legal alibi of the protection of minorities.

Key Words: religious freedom, calamities of the law, orientalism, minorities, identity, sharp right.

La religión, con todo el poder que se le atribuye, intervenga de forma útil para [...] consagración suprema, y que la bondad misma de sus preceptos reclame la atención de quienes, teniendo la carga del bien común, están cualifcados para hacerlos pasar al derecho positivo. ${ }^{1}$

(Gény 2007, 62)

SUMARIO: I. Justificación. II. Introducción. III. Reacciones e inicio del proceso judicial. IV. La encrucïada registral. V. La encrucïada en Iraq. VI. La encrucïa-

del CSIC, por sus aportes a la última versión de este artículo, además de ambos señores revisores anónimos por sus valiosos comentarios y análisis que mejoraron considerablemente esta versión final

1 Con esa cita ilustrativa de Gény, no se tiene otra intención que la retórica. Es decir, el presente estudio se empeña precisamente en demostrar las calamidades de esa envoltura. ¡Veremos!

Esta obra está bajo una Licencia Creative Commons

Atribución-NoComercial-SinDerivar 4.0 Internacional, IIJ-UNAM.

Boletín Mexicano de Derecho Comparado, núm. 158, mayo-agosto de 2020, pp. 485-519. 
da en Túnez. VII. El origen de la calamidad. VIII. El papel de colonialismo europeo en la fragmentación de las identidades sociales. IX. Epilogo. X. Bibliografia.

\section{JUSTIFICACIÓN}

El presente estudio gira alrededor de tres entornos jurídicos, el iraquí, egipcio y el tunecino. La razón de escoger estos tres ejemplos como botón de muestra se debe a motivos, objetivos y subjetivos. Principalmente, los primeros dos representan el satélite intelectual y jurídico de referencia para el mundo árabe. Es decir, la práctica jurídica y la doctrina, se dicta en estos dos países, y de ellos se propaga para el resto. El movimiento de codificación civil, por ejemplo, nació en Egipto en 1871, el actual Código Civil egipcio es de 1949, replicado por el mismo rector en Iraq en 1951, y posteriormente copiado y promulgado en Libia en 1970; Jordania en 1976; Kuwait en 1980, etcétera. Por lo que analizar estos dos casos, además de su arraigo histórico y lo que representan estos dos Estados, ejemplificaría y daría a entender el conjunto de la práctica jurídica en el mundo árabe oriental. El segundo motivo se refiere a Túnez. Si bien optar por ese ejemplo se debe a otros dos motivos. Primero, porque la práctica jurídica en el mundo árabe occidental (magrebí) es, en alguna medida, distinta y distante al primer contexto (el mundo árabe oriental), y por razones históricas y del curso del tiempo. Pues los Estados de este contexto, todos ellos (a excepción de Libia), son excolonias francesas, se cuajaron y se independizaron del colonialismo francés muy tardíamente después de la segunda guerra: Túnez en 1964; Argelia en 1962, y Marruecos en 1956, aunque con relativa efectividad. El segundo motivo, es que Túnez representa el ejemplo más madurado teóricamente desde la perspectiva jurídica; fronteriza entre una categoría occidental y un distintivo oriental. Referirse al ejemplo tunecino representaría la madurez jurídica positivista en comparación con marruecos como un régimen muy caracterizado por los rasgos del antiguo régimen monárquico, y la particularidad técnica de Argelia.

Además de todo lo anterior, el presente estudio pretende demostrar la práctica jurídica en sociedades pluriétnicas, y plurideológicas, y estos rasgos no se dan sino en los Estados referidos en la presente muestra. Se descarta el caso libanés, aunque también representaría un modelo pluralista, primero por ser un lastre traumatizado que pudiera considerarse 
jurídicamente un fracaso técnico - literalmente guerra civil propulsada por factores ideológicos, 1975-1990 - por tanto, dada su inestabilidad, debería ser expuesta, y posiblemente comparada en un artículo o capítulo seguido aparte del presente.

Suma a todo lo anterior, la calamidad rubricada en el presente artículo, que es el tractor principal y la hipótesis que se pretende demostrar: cómo estaban estos contextos jurídicos, y cómo de calamitoso resultó la interferencia colonial en sus prácticas jurídicas y la implantación de derechos subjetivos punzantes, hirientes a su cohesión social interna, y que a pesar de ser un reclamo de las potencias extranjeras como un derecho subjetivo de identidad y pertenencia, no resultó ser más que un derecho punzante, dañino a sus categorías socio-jurídicas.

Cabalmente se pretende abordar la calamidad jurídica resultante de la intervención en Iraq desde 2003, y desde una perspectiva más práctica que teórica. Es decir, analizando la praxis jurisdiccional más que los debates teóricos y doctrinales escolásticos, ello además por dos motivos. El primero es consecuencia de los propios hechos y su magnitud, en el caso de Iraq. Pues las tribunas escolásticas sufrieron profunda extirpación de todo el gremio académico: en la mañana de la invasión, en 2003, la sociedad iraquí no solamente amaneció huérfana de su padre, el Estado y las instituciones, sino también de su madre engendradora de su producción científica y doctrinal. García Pelayo en su división de las identidades nacionales entre naciones estériles y otras en progreso se refiere a la "existencia de clase social capaz de generar en cada momento histórico, la cultura nacional" (García Pelayo 1981, 49). Pues, en el caso de Iraq, entre 2003 y 2004, unos 4500 a 6000 profesores universitarios iraquíes de todas las clases y disciplinas intelectuales y científicas fueron asesinados selectivamente bajo distinto argumento de extirpación de los rasgos del antiguo régimen, eso sin contar los que lograron salvar su vida y huir del país para terminar en un exilio en la sombra. ${ }^{2}$ Hecho que supone profunda este-

2 Las cifras de víctimas civiles de la invasión de Iraq son objeto de gran vaivén dada a absoluta ausencia de organismos oficiales que lo ofrezcan, por el desmantelamiento abstracto del conjunto del Estado y las instituciones iraquíes por la autoridad colonial en abril de 2003. El Instituto Waston lo cifra cabalmente en 182 miles (Crawford 2018), mientras que el Plos Medicine siguiendo otro método más aritmético lo eleva a medio millón (Rawaf 2013), cifra coincidente con la de 405 mil, propuesta por (Hagopian et al., 2013), aunque otros colectivos locales lo elevan a unos 800 miles (Iraq Body Count s. f.). 
rilización social que además se diagnostica en el presente artículo como originador de una sublevación intelectual caracterizada, entre otras, por una revolución sociolingüística en la práctica jurídica, ${ }^{3}$ y que además se manifiesta en la carencia de estudios nativos en la temática, por lo que el presente artículo se centrará en contrastar la jurisprudencia de los tribunales aludiendo apenas a los escasos estudios existentes.

La calamidad, hipótesis principal del presente, se postula como uno de los problemas referidos por Smelser de una prosperidad al portador Ready Made Prosperity (Smelser 2013, 180 y ss.), que se identifica como una reacción silenciosa a una implantación forzadamente impuesta y calamitosamente gestionada por el personal asesor de las potencias extranjeras, que en muchos casos, actúan simplemente como traductores, antropólogos y orientalistas, hoy llamados estrategas, ${ }^{4}$ intrusos y ajenos globalmente

3 Revolución, más que evolución, dado que la sociolingüística sostiene que la evolución lingüística intergeneracional es un rasgo esencial de sobrevivencia lingüística (Hockett 1960), aunque debe progresarse integeneracionalmente, es decir, paulatinamente ente dos a cinco décadas (Moreno Fernández 2009, 269 y 270). Sin embargo, en el caso de Iraq se aprecia una revolución-sublevación de las categorías lingüistas y los actos del habla demuestran una sublevación del estrado vulgar y diglose a las categorías legislativas y jurisdiccionales (Alnasir 2019, 26).

Pues a pesar de que las palabras constituyen el modo de categorizar la realidad, impregnando en ellas todas las cosas (Conde 2010, 230), su estudio en el campo jurídico (lenguaje legislativo-jurisdiccional) es una perspectiva muy fértil para el estudio, y escasamente abonada por los juristas, y que en el presente se pretende abordar como una de las secuelas de la interferencia extranjera poco atendida por los juristas. En cuanto a aspectos de vigilancia, el Tribunal Constitucional español negó reiteradamente su competencia para depurar el lenguaje legislativo, no siendo materia de control de constitucionalidad (STC 58/82 1998) reiterada en (STC $37 / 87$ 1987), y (STC 99/87 1987) afirmando que "por el principio de seguridad jurídica se refiere, ya hemos dicho en retiradas ocasiones que la mera existencia de incorrecciones técnicas o formales no sería motivo suficiente para declarar la inconstitucionalidad de las disposiciones que incurren en la misma, sino que constituyen materia ajena a la jurisdicción constitucional, pues no es misión de este Tribunal depurar el lenguaje legislativo".

Sin embargo en el presente caso se manifiesta como uno de los sintamos de la calamidad y el cambio - inversión, que dificulta el estudio del caso. Pues las secuelas de la interferencia colonial en Iraq se demuestran no solo en la calamitosa reversión de los derechos de libertad religiosa y su ejercicio, como se demuestra en los casos de estudiados, sino también en el desorden teórico y normativo de las instituciones instauradas por las potencias extranjeras presentando además un dilema sociolingüístico en el campo del derecho.

4 Edward Said, en el prefacio de la edición, de 2003, de su obra universal Orientalism (1978), ya se manifestó en contra del lobby intelectual y mediático en Estados Unidos como 
a toda noción o formación jurídica y toda particularidad socio-jurídica de las sociedades orientales, que a su vez podemos rubricarla como uno de los problemas propios de una globalización forzada.

\section{INTRODUCGIÓN}

La religión en el mundo árabe es más que un constructo de pertenencia e identidad, un drama de libertad que adquiere cada día más aversividad social causando a su vez una esquizofrenia identitaria y desorden normativo. ${ }^{5}$ Ese drama no se debe a la religión en sí como ideología, sino más bien como oligarquía instrumentalizada institucionalmente. La diferencia radica en la definición. Las sociedades europeas, a excepción de España, se cuajan como un synoikismo, ayuntamiento de moradas basado en un sistema de incorporaciones en el sentido romano-latino (Ortega y Gasset $1921,8)$. Una especie de cohesión promovida por un interés recíproco de compartir vecindad por un proyecto común impulsado por dejar la vida nómada salvaje, fortalecerse mutuamente y establecer una coagulación geoestratégica. ${ }^{6}$ Esta identidad histórica marca la identidad social europea en diferencia con la árabe y de todo orden.

propulsores del discurso beligerante, arrogante, hegemónico y de la transbordación del rule of law americano sin tener conocimientos de causa ni en las propias categorías jurídicas americanas, ni en los rasgos identitarios de las sociedades medio-orientales (Said 2003, 14 y ss.).

5 La esquizofrenia socio-jurídica, o socio-política en los entornos medio-orientales ha sido identificada como un trastorno de esterilización social y fracaso colectivo plasmado entre entes políticos carentes de identidad ideológica (definidos como partidos políticos o grupos de agitación colectiva), propuestos con ansiosa búsqueda de identidad compensatoria (ficción histórica, alarma conspiratoria o hasta compensación escatológica), e influidos a su vez por constructos vicarios al interés colectivo que son las instituciones religiosas que asientan el incontestable forjamiento dogmático compensatorio, acorralando a los colectivos así en un laberinto de búsqueda, intramuros, de pertenencia (Alnasir 2019).

6 Las tres guerras púnicas lideradas por el Imperio Romano contra Cartago (actualmente Túnez), su principal propulsor era evitar el fortalecimiento de Cartago que pudiera desafiar en algún momento a Roma. En la segunda guerra púnica (218-201 a. C.) los romanos impusieron a los cartagos severas condiciones para asegurar su debilitamiento, entre ellas era el pago de unos 200 talentos de plata durante medio siglo además de prohibirles disponer de barcos de guerra, ni declarar la guerra contra nadie sin su previa autorización. Sin embargo cuando a mediados del siglo II a. C. el censor romano Marco Porcio Catón, conocido como Catón el viejo, visitó Cartago observó asombrosamente su próspe- 
La tradición histórica creada en Europa se manifiesta como un método más etnográfico que jurídico formando por tres ejes, la tierra como identidad, fuente de riqueza, es decir, vínculo económico y de sostenimiento, además de objetivo de propiedad y por ende de pertenencia identitaria; la sangre como curso troncal de las generaciones, y las alianzas que estampan; además del tiempo como factor de progreso y amoldamiento paulatino de la cohesión (Grossi 2007, 26 y ss.); sin embargo, el miedo en las sociedades europeas-occidentales, como un constructo de forjamiento grupal, un propulsor del ayuntamiento de moradas identificado por Ortega, aunque posiblemente no recogido como tal por Grossi. Pues a los tres elementos de coagulación etnográfica europea sangre, tierra y tiempo habría que añadirles el miedo como un constructo cognitivo de unión socio-política irrenunciable en la sociedad occidental tal y como lo definió Robin (2004), que en el mundo árabe es totalmente distinto, pero era la perspectiva colonial de occidente que intentaba implementarlo como tal presumiendo sus propios constructos pero obviando los de los árabes exhaustos del apoderamiento desfrazado instrumentalizador de la religión desde las guerras de sucesión hasta la colonización otomana desde el siglo XV hasta la Primera Guerra Mundial. Por lo que a pesar de ser la religión un constructo social de adhesión nunca habría sido bien recibida su institucionalización, al no ser otra que un signo colonial ajeno a los constructos social, sino una piedra vicaria de dominio político. Eso no se refiere sólo a la religión islámica, sino igualmente a la cristiana. Pues las iglesias orientales, principalmente la copta de Egipto, la asiria y la aramea de Iraq, y la ortodoxa de Siria, además de la congregación lucana todas ellas se forjaron al hilo de contiendas y alianzas entre poderes extranjeros

ra, rica y rápida recuperación, cuando realmente esperaba hallarla hundida en la miseria y las consecuencias de las severas condiciones impuestas por el acuerdo de rendición, hecho que motivó su empeño en convencer al senado romano para lanzar una guerra preventiva pero destructiva definitivamente a Cartago que evite un posterior levantamiento de los cartagos contra Roma bajo su famosa aclamación de que "Carthago delenda est" (Cartago debe ser destruida) (Baños 2017, 41-43). Sin embargo la oposición del senado liderada por los escipiones se basaba en la necesidad de conservar el peligro de Cartago como único adversario que tenía la utilidad de unión y fortalecimiento de Roma, que de abatirla el pueblo caería en relajamiento en la disciplina y la austeridad que habían servido para el fortalecimiento del imperio y la grandeza de Roma, por lo que eliminar ese miedo estratégico desembocaría en una decadencia que acabaría con la unidad del imperio romano, y eso fue precisamente lo que ocurrió una vez abatida Cartago (Baños 2017, 227). 
promovidos ente el Impero Romano y el Pérsico impulsando los únicos contra los otros masacrando y destruyéndose unos otros por medio de los pueblos para servir a intereses totalmente ajenos a los dogmas religiosos como tal. Wojciechowski demostró mediante una construcción histórica del cuajamiento del poder patriarcal oriental cómo las iglesias orientales terminaron liquidándose la una contra la otra para terminar imponiendo su dominio sobre los pueblos (Wojciechowski 2002).

A continuación, veremos varios casos jurisdiccionales de Egipto e Iraq principalmente, cómo la religión, o más bien las instituciones patriarcales de la religión ejercen un férreo poder, en algunos casos, incluso, bi-estatal avivado por influencias extranjeras, acorralando a los individuos en un laberinto jurídico y derechos, supuestamente subjetivos, pero cuya única utilidad es la de fortalecer a las instituciones patriarcales y perjudicar severamente a los ciudadanos. Veremos como, bajo el pretexto de identidad religiosa y la protección de identidades minoritarias, se crearon asientos registrales para, además de asegurar la identidad-pertenencia como derecho, sirvieron a intereses espurios de extender la tutela a instituciones subestatales que terminaron por imponer un dique a todo tipo de libertades individuales, y bajo ese pretexto de asegurar el derecho a la identidad religiosa y la pertenencia, todo un ejemplo de un derecho de doble filo que se propone definir como derecho punzante.

En el Tribunal Administrativo de El Cairo, en el expediente número 10838 del año jurisdiccional contencioso-administrativo número 58 (STAG 10838/58 2007), ${ }^{7}$ pleita una multitud de demandantes y demandados por un relato de los hechos referente a una ciudadana de confesión cristiana "copto ortodoxa". La referida ciudadana, esposa de un sacerdote de su misma confesión, según el relato de los hechos, fue atraída por un programa de televisión, por lo que dice haberse convertido al islam en la intimidad y practicando secretamente los ritos de esta confesión durante dos años. Profundizando en su acercamiento a esta ideología, descubrió

7 La jurisprudencia referida en el presente estudio se extrae de las bases de datos oficiales de cada organismo referido, y son traducidos por este proponente al castellano en lo que afecta al presente estudio, salvo las citas del Tribunal Supremo de Israel, son recogidas de otro auto que se citará en su momento. Cabe destacar en el caso de Egipto que la jurisprudencia se cita por cada orden jurisdiccional atendiendo el año jurisdiccional desde su implementación; es decir, la referencia aquí, año jurisdiccional administrativo egipcio 58, se refiere a 2007.

Esta obra está bajo una Licencia Creative Commons

Atribución-NoComercial-SinDerivar 4.0 Internacional, IIJ-UNAM.

Boletín Mexicano de Derecho Comparado, núm. 158, mayo-agosto de 2020, pp. 485-519. 
que no debería mantener su matrimonio y convivencia si su marido no asumiría junto a ella esa confesión, por lo que decidió abandonar el domicilio conyugal y dirigirse al de uno de sus allegados. Le informan entonces que la norma civil de su país le obliga a realizar unos trámites declarativos de cambio de religión. Para ello decide acudir a una comisaría de policía de su proximidad, declarando haberse convertido al islam, por lo que solicita que se le expida el correspondiente testimonio de conformidad del ministerio público para proceder a la modificación en sus registros filiales.

Según el mismo relato de hechos, del 2 de diciembre 2004, tras las correspondientes averiguaciones, el ministerio público competente acuerda admitir a trámite la pretendida solicitud. En consecuencia, y en virtud de lo establecido en el acuerdo del Estado egipcio con la congregación copta, la autoridad debe iniciar previamente un tramite de audiencia con la congregación perdedora para que ésta pueda ejercer lo que en su derecho estime oportuno, como el intento de retención y conservación de sus feligreses. Es decir, el acuerdo del Estado con esa congregación le otorga la tutela subjetiva de sus feligreses para que tome medidas de retención o impida el transfuguismo religioso, como si fueran clientes en la economía de mercado. Informada la interesada sobre las pautas del trámite, aceptó, por lo que el Ministerio Público acordó entregarla al representante local de su congregación de origen, quien tendría un plazo máximo de 24 horas para re-entregarla al poder público con la preceptiva propuesta de conformidad u oposición, según el caso. Es decir, en este caso, un ciudadano que desee ejercer su libertad de conciencia y practicar el transfuguismo religioso no sólo debe declarar el hecho, sino que además pierde tácitamente su libertad, ya que queda en situación de detención fáctica bajo la tutela de las autoridades administrativas y religiosas hasta que se decida su pertenencia ideológica y filiación a una u otra autoridad religiosa. Este caso tuvo gran repercusión mediática, además de coincidir con las fechas navideñas, lo que llevó a que el Papa copto cancelara su liturgia de Navidad y decidiera acudir personalmente a la sesión correctora. Pues según los rituales de la Iglesia copta, la apostasía se a la herejía, desobediencia, entre otros supuestos de la máxima gravedad. ${ }^{8}$

8 Sin ir lejos, la Iglesia católica tampoco tiene fácilmente establecido el mecanismo de apostasía. No obstante, ese trámite en las sociedades occidentales es un mero acto voluntario y declarativo sin efectos jurídicos ni civiles. Pero en los casos del presente examen 
Una vez trasladada la imputada a la parroquia de la Divina Pastora de El Cairo, donde la esperaba el Papa copto interesado en dirigir personalmente la sesión de su corrección espiritual, y antes de entrar a la sala del tribunal, según el relato de hechos de la sentencia, la interesada solicitó un receso para poder celebrar su oración según su nueva confesión, es decir, para poder rezar según la religión islámica, que tiene marcados los tiempos de oración cotidianos. Aquel hecho, dice la sentencia, causó gran furia del Papa copto, quien decidió retirarse del tribunal y todo el entorno para marcharse a un monasterio a las afueras de El Cairo, dejando los demás miembros del referido tribunal a cargo de los trámites pertinentes de la sesión correctora. Celebrada la sesión de corrección, la referida rectificó y confesó haber incurrido en un error, según relata la sentencia. Entonces fue acompañada por un letrado de la parroquia a la comisaría de origen, donde declaró su rectificación ante el fiscal instructor, quien acordó ponerla en libertad, dejando sin efecto el trámite iniciado y ordenando, por consiguiente, el archivo del caso. ${ }^{9}$

suponen un peliagudo laberinto, dado el poder que ostenta la Iglesia en estos países, y el alcance jurídico-civil en la filiación y la determinación, no solamente del estatus civil, pero también del fuero jurisdiccional. Es exactamente a lo que se refirió Luhmann, que en estas sociedades funcionalmente diferenciadas la religión juega un papel determinante como un sistema funcional que ha ganado autonomía-poderío a costa de reconocer la autonomía a otros subsistemas, como la secularización (Luhmann 1977, 225) recojo nota de (Luhmann 1985, 14).

9 He aquí el relato oficial que recoge el texto de la sentencia. No obstante, en la prensa local e internacional transcendieron otros relatos, que además demuestran varios aspectos. Primero, dada la delicada situación de esta persona, por ser esposa de un sacerdote copto, la Iglesia copta se postuló el caso como un ataque institucional a su dignidad, y que además, por práctica habitual, la Iglesia copta ante la conversión de cualquiera de sus miembros, directamente se postulan el asunto como desaparición forzada, elevándolo a denuncia pública mediática, interesando en sendas ocasiones la mediación internacional ante las autoridades del Estado para que les entreguen referido sujeto, aún en contra de su propia voluntad. Este caso concretamente suscitó una crisis internacional a gran escala. Una asociación que postula la defensa de los derechos civiles de los coptos de Egipto con sede en Washington llamó a la mediación del presidente Israel y al de los Estados Unidos de América para presionar a las autoridades egipcias para la entrega de la referida persona, y a su raíz se presentó una iniciativa parlamentaria interesando la expulsión del embajador de los Estados Unidos de Egipto por interferencia en asuntos internos (Middle East online 2004), dado que además la Iglesia copta promovió violentas manifestaciones a las afueras de la comisaría de la policía en cuestión, resultando de ella violentos altercados y la detención de unos 35 individuos (Aljazera 2004) y (Aljazera 2015).

Esta obra está bajo una Licencia Creative Commons

Atribución-NoComercial-SinDerivar 4.0 Internacional, IIJ-UNAM.

Boletín Mexicano de Derecho Comparado, núm. 158, mayo-agosto de 2020, pp. 485-519. 


\section{REACGIONES E INICIO DEL PROGESO JUDICIAL}

Las reacciones a la noticia no se hicieron esperar. Un clérigo de la Universidad de El Azhar ${ }^{10}$ presentó demanda contencioso-administrativa contra el fiscal instructor del caso, por haber entregado la referida ciudadana a las autoridades eclesiales y por su conclusión posterior de la instrucción. El recurrente alegó en su recurso que las actuaciones practicadas no son conforme a los principios generales de la religión islámica, vinculantes para el Estado egipcio en virtud del artículo 2o. de la Constitución. Alega una norma del islam que no permite entregar un musulmán que haya optado libremente por la confesión islámica a quien no lo es (Qurán 66, 10). Subsidiariamente alega que, siendo ya musulmana, el islam no permite la renegación inversa de la fe islámica una vez convertida a ella, dado que la referida ya había declarado haberse convertido al Islam y practicado sus liturgias durante los dos años anteriores al día de su comparecencia y declaración. Es decir, ella compareció declarando haberse convertido ya plenamente, no solicitando la conversión.

El recurrente se apoya en la vinculación del Estado a los principios generales del islam establecidos en el artículo 2o. de la Constitución egipcia de 1970 tras su reforma de 1980. En su recurso alega, además, la legítima potestad para sostener la demanda, suponiendo el doble fuero compe-

10 El Azhar, aunque por nombre lleve la distinción de "Universidad", es además el máximo órgano religioso islámico de Egipto, que ostenta toda la representación, autoridad institucional y de supervisión, además de la educativa, relacionada con la religión islámica en el país. Es un homologo del patriarcado copto (cristiano-ortodoxo) de Egipto. Ambos actúan a la postre como agencias independientes autoreguladas y de derecho público. Es el único órgano existente, como tal, en un Estado musulmán en la actualidad. No en vano algunos medios de comunicación, ignorantemente, lo designan como el máximo órgano religioso del islam, lo que es una aberración absolutamente ajena a la realidad. Es el máximo órgano institucional de Egipto, nada más, sin ninguna transcendencia transnacional. Otra cosa, es que ostenta el respeto y la veneración académica, y formativa como institución científica. Es cierto que en Túnez existe algo similar, el Qairawan, pero éste sufrió importantes debilitamientos por los sucesivos gobiernos postcoloniales, por lo que acabó siendo un museo, una simple institución académica y arcaica. Esta situación destaca como uno de los problemas de la deriva identitiaria y autoritaria en Túnez. En los demás Estados musulmanes, la religión o bien es apadrinada por el propio Estado mediante el ministerio de asuntos religiosos u otros órganos ad hoc, como es el caso de Marruecos y en alguna medida, también de Jordania. Van Bruinessen elaboró un trabajo comparativo sobre las autoridades reguladoras de Turquía e Indonesia (Bruinessen 2018). 
tencial - el civil estatal y el espiritual penitenciario correspondiente al Azhar - por lo que recurre el hecho de la entrega y solicita el retroceso de las actuaciones, la devolución de la interesada y su entrega al centro religioso de El Azhar en base a su protectorado sobre la comunidad islámica en Egipto. Finalmente, considera y solicita que la referida persona debe ser procesada por apostasía, que es el más grave delito en la fe islámica.

El recurrente se apoya, en primer lugar, en la vinculación del Estado a los principios generales del islam establecidos por el artículo 2o. de la Constitución egipcia en su reforma operada de 1980 que, en su versión original de 1970, decía que "El islam es una fuente oficial para el legislador". Tras la reforma de 1980 pasó a decir "El islam es la fuente oficial para el legislador". Por ello, y en su virtud, el recurrente alega suficiente legitimidad activa para sostener el recurso, ya que, a su entender, la citada reforma habría creado un doble fuero concurrente entre el Estado y la religión representada por su máxima autoridad congregacional en Egipto, El Azhar. A su entender, ese mismo precepto le habría otorgado un fuero penitenciario para aplicar sus propias normas religiosas en cooperación con el Estado. Por ello, sostiene el fondo de su demanda contra el Ministerio Público que autorizó la entrega de la referida ciudadana a las autoridades eclesiales por primera vez, su posterior puesta en libertad y el archivo de la causa al día siguiente, todo ello sin informar a la autoridad Islámica en su condición de protectorado de la comunidad islámica de Egipto. Insiste, además, en anular los hechos de la primera entrega y, subsidiariamente, de la segunda, e incoar el correspondiente procedimiento penal por apostasía de la fe islámica, según establecen las pautas de esta confesión.

Es menester destacar que el relato de la sentencia no recoge, ni parece que el recurrente haya impugnado directamente, el acuerdo del Estado egipcio con la congregación copta por no estar conforme con la nueva versión del artículo segundo de la constitución, ni que haya planteado la cuestión de tutela pública en virtud de dicho artículo, tampoco reclama igualdad de trato de la autoridad islámica con la copta.

Como consecuencia de la repercusión mediática del caso, se adhirió al proceso una multitud de actores de ambas congregaciones, la musulmana y la cristiano-copta, asociaciones de derechos civiles y un largo número de actores de la sociedad civil respaldando a cada bando. En su referida sentencia del 24 de abril 2007, expediente 10938 del año contencioso-ad- 
ministrativo número 58 (STAG 10838/58 2007), el tribunal, en sus razonamientos jurídicos, se detiene en que el contenido vinculante del Estado con la religión islámica plasmado en el artículo 2o. de la Constitución es una mera declaración política que vincula a los poderes político y legislativo, pero no comprende ninguna noción jurídica para los demás poderes del Estado, ni judiciales ni administrativos. Es decir, suponer que el islam es la fuente del ordenamiento no conlleva que lo sea para la administración, cuya vinculación es únicamente con el derecho positivo emanado del legislador (STCEG 55/22 2001). Añade, por tanto, que las vías de protección contra las acciones emanadas del legislador son sostenibles ante el tribunal constitucional en acciones directas contrarias a la ley, no ante la jurisdicción administrativa, ni mucho menos contra actuaciones administrativas. Además, considera la carencia de legitimación activa por parte de los actores de ambos bandos, al tratarse de una libertad individual, dado que la interesada había comparecido inicialmente en la comisaría por su propia voluntad y al ser entregada por las autoridades policiales a las eclesiales y devuelta por éstas, y que por su propia voluntad declaró que "su fe natal es la cristiana, que había confesado toda su vida, y que con ella morirá". Todo ello en los términos que se recogen literalmente del atestado levantado al efecto en una declaración que contaba con la fe pública procesal del fiscal instructor. Por ello rechaza, además, llamar a la interesada — según solicitaba alguna de las partes - para que vuelva a manifestar ante el tribunal su intención sobre la fe que desee practicar. Finalmente se desestima íntegramente la demanda en ambos términos y a todos los efectos.

Es obvio que, a nuestro entender, este caso levantaría reclamaciones, repulsas y críticas de todo tipo, pero la calamidad, lo más triste de ello, aún apareció fuera del juicio. Aparte del contenido de la sentencia y toda la contienda legal, lo más trágico vino después, en la prensa local del día siguiente a la publicación de la sentencia, cuando los medios egipcios difundieron la noticia de que se había hallado al cuerpo de la referida ciudadana "sin vida" en un convento de monjas al que había sido enviada en un retiro penitenciario. Estos fueron los términos: "hallado el cuerpo sin vida en un convento la que fue enviada a un retiro penitenciario". ${ }^{11}$

11 La noticia de su muerte aparece recogida en unos medios, sin embargo, la Iglesia copta mantuvo en silencio, a pesar de transcender otras noticias de su posible aparición en 


\section{LA ENCRUCIJADA REGISTRAL}

La encrucijada de ese ángulo registral contiene aún muchos más ejemplos y supuestos de lo que cabe imaginar. Con el abanico de supuestos, existe otro de respuestas judiciales que han ido intentando respaldar la libertad individual, creando una línea divisoria entre las declaraciones decorativas de las cartas constitucionales y los principios opacos que en ellas se albergan, en defensa del derecho a la libertad individual, pero más e imperiosamente de la positividad del derecho. El objetivo es impedir que la imbricación/bicefalia del derecho con la religión termine con una forma de huida y vía de escape de la normatividad (Alnasir 2019, 98). Es obvio que la práctica merma una protección que en muchos casos depende no sólo del poder público, de una decisión individual o populista de uno de sus agentes, sino también del conjunto del entorno social y de la labor mediática que ejercen los medios de comunicación agitando en una u otra dirección.

En efecto, la sentencia, del 9 de febrero de 2008, del Tribunal Administrativo de El Cairo tuvo que lidiar con el caso de un ciudadano de origen cristiano copto que se había convertido al islam y, presionado por su entorno social de origen, dice la sentencia, decidió retractarse y volver a su confesión cristiana. ${ }^{12}$ Dicho cambio-retroceso le fue denegado por el encargado del Registro Civil, quien entendió individualmente que el Estado egipcio está sujeto a la religión islámica en virtud del artículo 2 o. de la Constitución anteriormente comentado, y que por su parte la religión islámica no sostiene la posibilidad de renegar de ella. Para entonces, el Tribunal Administrativo de El Cairo le había ordenado al recurrido encargado del Registro Civil a que procediese a la interesada inscripción,

una cadena de televisión copta, respondió el Papa copto de que la referida se encuentra recluta en un convento cristiano, dedicada a la devoción y sujeta a un lavado de cerebro de lo que le habían sometido y no tiene ningún interés en exponerse ante los medios (Alarabiya 2008).

12 Los motivos transcienden el propósito de este estudio, aunque en el caso tunecino repasaremos parte del mismo. Si bien en ese caso se relató que el motivo fue el nombre propio, ya que los cristianos egipcios usan nombres mayoritariamente hebreos, y aunque le hicieran el cambio de fe y constara en la cédula de identidad musulmana, seguirá manteniendo el mismo nombre y apellido, lo que revela claramente que fue cristiano. Hechos que le causan estigmatización en la nueva comunidad, además de persecución por parte de su comunidad de origen. Volveremos con más ejemplos más adelante con el caso tunecino. 
haciendo constar en el asiento la mención, sin precedentes, de: "Copto cristiano, musulmán anteriormente".

Tal casuística en Egipto demuestra un sinfín de conflictos promovidos por el férreo poder de la Iglesia copta de Egipto sostenida por el exterior bajo el postulado de protección a las minorías y la libertad religiosa y cuajada como un Estado dentro del Estado egipcio ('rft 2010) y (Al'wạ \& Mnșwr 2010). Por otra parte, el transfugismo entre cristianos hacía el islam se debe, en gran medida, a una práctica de fraude de ley, para huir del fuero jurisdiccional copto que prohíbe el divorcio y mantiene férreas normas matrimoniales y de castigo a la disolución matrimonial. Por ello se dan los casos en los que varios ciudadanos optan por convertirse al islam, para conseguir con ello someterse a la jurisdicción de ese fuero, divorciarse según establece esta jurisdicción, volver a casarse nuevamente según esta orden, y volver a solicitar su regreso a su fe de origen alegando haberse resentido instando la polémica rectificación del asiento registral.

\section{LA ENCRUGIJADA EN IRAQ}

En Iraq se desconocía tal problemática con anterioridad a 2005, aunque también existía ese precepto registral. El Estado, en todo caso, era el titular de todas las potestades públicas y ninguna confesión revestía identidad jurídica propia. Todas caían bajo el paraguas de la identidad estatal, a pesar del contenido del artículo 4o. de la Constitución de 1971, que se limitaba a declarar que "el Islam es confesión del Estado", sin especificación ni imposición material a los poderes del mismo, es decir, quedando desde entonces como mera declaración opaco-política en un Estado materialmente civil, positivo, e institucionalizado. El problema surge del documento redactado por los aprendices y becarios de la coalición democratizadora estadounidense, que lo rubricaron como "Constitución" de 2005, cuyo artículo 2o. proclamó que "el Islam es la confesión oficial del Estado, siendo fuente principal para el legislador", a saber que este artículo ha sido enérgicamente criticado por varias organizaciones de derechos humanos, no sólo desde el esquema del sectarismo y la fragmentación social, además por inducir desigualdad subjetiva y un desorden subestatal más dañino que lo que parezca como beneficioso (Minorities and the Law in Iraq 2011). 
En la práctica jurisdiccional que relata la jurisprudencia del Tribunal Iraquí de Casación (STCI 1741/2008, 2008), surgió un procedimiento de rectificación registral por el que el encargado del Registro Civil admitió la instancia de un ciudadano musulmán que, aportando una certificación bautismal de una comunidad eclesial cristiana, se interesó en modificar su filiación de musulmán a cristiano. La praxis iraquí, como comentábamos, es diferente de la egipcia, pues siendo el Estado el titular único de la soberanía, o así lo era, no se comunica a ningún ente las modificaciones referentes a ningún ciudadano, sino que la normativa registral - del antiguo Estado institucional, aún vigente-- siendo pública, establece la simple obligación de publicar cualquier alteración registral que se practique mediante un edicto en la gaceta del Registro Civil. Hecho muy similar y común a cualquier otro país de las categorías del estimado lector. Así, y ante la publicación del edicto, un representante del Ministerio Público recurrió la referida modificación, cuyo recurso fue denegado, por lo que llegó finalmente al Tribunal de Casación.

En el recurso se sostiene que el Estado actual, por imperativo del artículo 2o. de la Constitución de 2005, se ve sometido imperativamente a los mandamientos doctrinales del islam, el cual, a su vez, no permite la alteración registral practicada, por lo que se interesa su anulación. Es menester destacar la dificultad para comprender la sentencia, dada la sublevación lingǘstica y profesional que padece el país democratizado desde 2005 (Alnasir 2019, 26). La redacción de la sentencia no parece estar clara, si bien el edicto debería haberse realizado antes de practicar la modificación del asiento y no con posterioridad. Es un trámite previo, no post facto. Sin embargo, del relato parece desprenderse que se recurre por haberse practicado la modificación, por lo que se interesa declarar su nulidad. En su resolución casacional, el tribunal iraquí, sin motivación ni argumentos - en una escueta resolución de dos líneas-, acuerda dejar nulo y sin efecto el cambio practicado por entenderlo contradictorio con la religión islámica, que no lo permite, en virtud de la vinculación del Estado a esa religión impuesta en el apartado primero del artículo 2o. de la Constitución de 2005, donde se dice que "El Islam es la confesión oficial del Estado, siendo fuente principal para el legislador"; es decir, mediante esa interpretación, en comparación con el caso egipcio visto en los apartados anteriores, se amplía la esfera de confesionalidad que se delimitó en Egipto para el legislador, la extiende en el nuevo Iraq — americanizado y 
democrático - para todo el Estado, haciéndola vinculante también para el juez y la administración, cosa que realmente la Constitución no dice, sino que literalmente el texto constitucional lo incumbe al legislador, no a las subsiguientes instituciones del Estado, pues en ese caso se daría una clara bicefalia normativa y jurisdiccional.

La calamidad no termina ahí, pues el tribunal de casación iraquí se inventa un nuevo procedimiento y remite el interesado a instar un proceso civil declarativo para que, mediante ello intente probar el cambio interesado, y que se le dicte sentencia declarativa que haga efectivo el cambio de religión. Es decir, por un lado, remite el justiciado a que inste un procedimiento inexistente en el ordenamiento jurídico que se lo inventa el tribunal y dice "declarativo para el cambio de religión", a pesar de haber anulado su pretensión por disconformidad con la Constitución, y se pronuncia ya sobre el fondo de la causa. O sea, no sólo lo anula por defecto procesal y lo retrocede para iniciar otro procedimiento, sino que lo hace prejuzgando tácitamente la causa como anti-jurídica, remitiendo al justiciado a otro calvario procesal, cuando ya el mismo tribunal lo dejó en prejuzgado como inconstitucional.

Este ejemplo pone en evidencia el gran revés que emergió en Iraq después de 2003 -2005. No sólo en el ámbito práctico-forense, sino en toda la disciplina jurídica, procesal, y hasta científico-conceptual. El desmantelamiento del Estado y las instituciones no solamente afectó a la forma y la apariencia, sino a la sustitución del personal al frente de las instituciones por personal lego investido sin fundamento técnico ni científico para ello. Eso se ve reflejado en actuaciones tan controvertidas como ésta, instada precisamente por el ministerio público. En esa sentencia se demuestra la gravedad de la situación actual de la judicatura iraquí. Siendo instancia casacional, casa la resolución recurrida y, haciendo referencia cabal a una base religiosa extrajurídica, remite al afectado a instar un procedimiento que no está tasado ni establecido por la legislación procesal, dice "declarativo para el cambio de religión" y, además de ello, anticipa los hechos posteriores, al concluir prejuzgando que el cambio de religión no es posible, ya que el Estado está sometido a la religión por mandato del artículo 2o. de la Constitución y que ésta, la religión, no permite tal cambio. ¿Para qué remite entonces el interesado a instar otro procedimiento declarativo, si el alto tribunal ya se situó sobre el fondo declarando la imposibilidad del cambio? Totalmente diferente a la situación anterior de Egipto, como 
demostramos cuando los tribunales tomaron distanciamiento de la postura religiosa delimitando su sumisión únicamente al legislador y dejando extramuros lo religioso, a las afueras de todo lo jurídico.

Con anterioridad a 2003, en Iraq la interferencia o implicación de la jurisprudencia islámica en el derecho positivo, en concreto en el ámbito penal, era impensable. Ello gracias al muy arraigado principio nullum $\mathrm{cri}^{-}$ men sine lege, implementado en el Código Penal Bagdadí de 1917 y en el posterior artículo 1o. del Código Penal de 1969. No era, de ningún modo, sostenible invocar ninguna acción penal basada en un principio ajeno al Código Penal.

El caso se dio en 1989 ante el consejo del estado iraquí, en el que se trataba de una condena a muerte por renegación del islam. En el relato de hechos se dice que se trataba de una ciudadana iraquí, de confesión musulmana, a la que se había denegado el permiso para contraer matrimonio con un compatriota de confesión cristiano-ortodoxa. La normativa vigente entonces prohibía a una mujer musulmana a contraer matrimonio con un hombre de otra confesión. Es decir, se trataba de una disposición normativa de derecho positivo tasada en la ley del estatuto personal iraquí número 188 de 1959.

La interesada, al haberle sido denegada su solicitud de matrimonio, salió del país y contrajo matrimonio en Grecia sin haber contado con la autorización previa de la autoridad consular para hacerlo, ya que, al parecer, el proceso local en dicho país no lo exigía. ${ }^{13}$ Es decir, acordó el matrimonio sin la previa instrucción y capacidad matrimonial establecida para ello, esquivando lo tasado en su normativa personal.

13 En la práctica actual este problema se da en cuanto a uniones del mismo sexo, cuando el país de origen de uno de los contrayentes no lo permita, no lo reconozca, lo prohíba, o lo penalice, siendo un jus connubii subjetivo e internacionalmente reconocido al portador (Calvo Caravaca \& Carrascosa González 2005). Sin embargo, esta práctica es bien conocida históricamente en este ámbito de patriarcado étnico-ideológico, que son los casos que ocupan el presente constituyéndose como una ventana de huida del asfixiante poder patriarcal religioso y su poderío subestatal, creando al efecto paraísos matrimoniales en los países más próximos y flexibles (Alnasir 2020). Hasta la actualidad este tema sigue sin lograr armonización internacional, ni siquiera en ámbitos regionales de consolidada proximidad normativa, como la Unión Europea, cuyos Estados miembros siguen cada uno aplicando sus propias normas de conflicto sin alcanzar un consenso intramuros, ni extramuros al efecto (Cebrián Salvat 2017, 7).

Esta obra está bajo una Licencia Creative Commons

Atribución-NoComercial-SinDerivar 4.0 Internacional, IIJ-UNAM.

Boletín Mexicano de Derecho Comparado, núm. 158, mayo-agosto de 2020, pp. 485-519. 
Así, y después de celebrar dicho matrimonio, en contra de su normativa personal, regresó al país casada y formando familia según el derecho griego. No aparece en el relato del caso si había solicitado la transcripción del matrimonio o si haya iniciado algún otro tramite más. La contienda comenzó por una denuncia que un clérigo musulmán interpuso ante el Ministerio Público para que se le imputara la responsabilidad penal por el abandono de la religión islámica, solicitando que se le impusiera la condena de pena capital, según establece la doctrina islámica por la renegación de la fe. En su denuncia se alegaba la vinculación del Estado a la religión, siendo el islam la confesión del Estado, según lo consagra el apartado primero del artículo 5o. de la Constitución de 1970, vigente entonces, y que rezaba: "el Islam es confesión del Estado".

Al parecer, y por primera vez, el Tribunal de Casación de Iraq, en una sentencia casacional sin precedentes, traspasó el límite del principio nullum crimen sine lege como fundamento básico para el derecho penal iraquí y confirmó la pena de muerte sobre una base puramente religiosa. ${ }^{14}$

Iniciada la fase de ejecución de la pena, ésta no se podría llevar a cabo sin la autorización ejecutiva del jefe del Estado, previo informe del consejo de estado, que se limitaría a corroborar la formalidad procesal y sus garantías.

Felizmente, el caso llegó al consejo del estado iraquí, que en 1989 emitió un dilatado, muy estudiado y acertado dictamen en el que manifestó su profundo malestar sobre el caso, ya que excedía la separación de la religión del Estado, además de invocar una condena a muerte no tipificada en el Código Penal, invadiendo el principio nullum crimen sine lege amparándose en una fuente manifiestamente extrajurídica, lo que suponía un grave precedente para el conjunto del ordenamiento jurídico. En su dictamen, el consejo del estado iraquí partió de la interpretación del

14 Cabe destacar un defecto manifiesto en la jurisdicción iraquí, que dificulta drásticamente el estudio, motivo por lo cual nos limitamos a la sumaria exposición de los casos. Ello se manifiesta en que la práctica jurisdiccional iraquí no es motivada. Es decir, las resoluciones judiciales iraquíes se publican únicamente con un breve relato de los hechos y la decisión, de forma muy escueta, en apenas una sola línea, sin expresión de motivación $n i$ ratio decidendi. Incluso en los órganos colegiados, las deliberaciones y argumentaciones son orales e internas para los órganos, y no reproducidos en las decisiones. Obviamente, este es un defecto de enorme gravedad, pero no es el objeto del presente artículo, por lo que hacemos este inciso a efectos ilustrativos de la comparación. 
artículo 5o. de la Constitución provisional de 1970, vigente en aquel momento, que disponía simplemente que "el islam es confesión del Estado". Este artículo, dijo, supone que la confesión islámica es rectora y directriz de actuación del poder político para mantener un marco de respeto y consideración moral hacía las instituciones religiosas. Sin embargo, no es vinculante para las instituciones del Estado ni supone ninguna ampliación esférica del derecho positivo hacía este orden moral, ni mucho menos en el ámbito penal, cuya única potestad radica exclusivamente en el Estado. El consejo de estado añadió, además, que las acciones penales son cuestiones de orden público, no susceptibles de supeditarse a ninguna categoría de orden espiritual ni extra-positiva, lo cual supondría un doble fuero penal que no tenía cabida en el orden constitucional entonces vigente.

De tal suerte que, en su conclusión, rechazó la propuesta de conceder el indulto, al entender el indulto como mera concesión subjetiva de gracia ante la ejecución, pero que no invalidaba la decisión en sí, manteniendo el precedente en el tráfico jurídico, cosa que rechazó globalmente. Por ello, la propuesta final del consejo al jefe del Estado, como titular máximo y garante de la justicia, fue casar íntegramente la sentencia y anular todas las actuaciones, entendiendo la acusación como improcedente e inadmisible desde su raíz y sin perjuicio del vicio civil que acarrea el matrimonio llevado a cabo sin el preceptivo tramite de capacidad civil, cuestión totalmente ajena a la jurisdicción penal. Así, terminó abordando un posible legis vacantis por el que proponía al legislador promover iniciativas legislativas para evitar semejante fraude procesal civil e incoar las preceptivas actuaciones disciplinarias contra quienes estuvieron implicados en la causa. ${ }^{15}$

15 La afectada en aquel caso, después de la anulación de la condena, fue recibida por el presidente de la república e indemnizada por los perjuicios que le fueron causados, en demostración de reparación de esa huida del derecho y de la intromisión de la religión en el mismo. Además, los jueces componentes del Tribunal de Casación y la Corte de Bagdad integrantes de la causa fueron procesados por prevaricación y separados del cargo. Lo curioso es que, una vez instrumentalizada la democracia de importación norteamericana, a esos mismos jueces se les restauró su estatus e incluso les reconocieron los años de suspensión y se les indemnizó, ya que alegaron haber sido perseguidos políticamente por sus opiniones y en contra de la independencia judicial. Incluso siguen ocupando la plana mayor de la jurisdicción iraquí, motivo por el cual hemos adelantado el primer ejemplo, que hace hincapié en la calamidad actual. 


\section{LA ENCRUGIJADA EN TÚNEZ}

A pesar de su similitud con los casos anteriores y la constante consagración constitucional de la confesionalidad estatal del islam, Túnez no cuenta con ese esquema de filiación confesional. Es decir, no existe un precepto declarativo de la fe, ni existe para ello un asiento registral en los registros públicos. La religión del Estado es el islam, dice el artículo 1o. de su actual Constitución de 2014 en consonancia con las cartas anteriores, pero el artículo 6o. de la carta dice que "el Estado es aparguador ${ }^{16}$ de la fe, garante de la libertad de conciencia, ideología y práctica religiosa, y neutralidad de las mezquitas y templos de cultos ante cualquier instrumentalización política de la religión" (Constitución de Túnez, artículo 1o.).

Sin embargo, de la conversión al islam surge el problema del nombre propio, primero por parte de los judíos, con significativo asentamiento sefardí, suponen una fracción muy menor de la población tunecina y tienen nombres tradicionales hebreos, muy señalados y reconocibles, además de otros individuos de otras procedencias cuyos nombres responden a una identidad cultural diferente. De ahí que el incipiente legislador tunecino de 1964, en la mañana de la independencia, tuvo esta circunstancia en cuenta, no precisamente por los judíos, sino por los restantes coloniales que permanecieron en suelo tunecino tras la retirada colonial francesa. Por ello, la ley número 20 del 20 de mayo de 1964 (Ley 20/1964, 20) auto-

16 Hago uso de ese término aparaguador que es inusual en la materia. Actualmente se usa en el derecho de las telecomunicaciones refiriéndose al operador primario gestor de la red física que ofrece el peaje de su red a otros operadores virtuales, MVO para interactuar con la red pública sin contar con instalaciones propias en el espectro. El aparaguador es sólo el propietario del dominio físico, ni es guardián, ni es visible para los beneficiarios finales, es simplemente proveedor de recursos. Y es en ese caso idéntico. El Estado es postfacto a la religión, ni es su guardián, ni es su creador. Garantiza el derecho a la libertad religiosa, pero no es su titular, ya que ésta preexiste a su creación, crea templos, pero simplemente es el titular del dominio afectado por la servidumbre de la religión, cuya misión es aparaguar los templos, y actuar, sí como guardián, para mantener su neutralidad y evitar su perversión. Esa misma perspectiva fue de las muy prematuras adoptadas en España por el Tribunal Constitucional español entendiendo prohibiendo al Estado a actuar en concurrencia con el ciudadano quien debe gozar de plena inmunidad de ningún signo de interferencia del poder público en su elección o práctica ideológica (STG 24/1982) reiterado en (STC 101/2004), siendo derechos previos al momento legislativo (formación del Estado), que originan por tanto el derecho a la inmunidad de regulación y tutela constitucional consagrado en el artículo 53 de la Constitución (STC 11/1981). 
rizó el cambio de nombre y apellidos a toda persona una vez adquirida la nacionalidad tunecina, y en su artículo 2o. autorizó a "todo tunecino que no cuente con un nombre árabe o africano, o que tenga interés legítimo para ello, que inste el procedimiento del cambio". Sin embargo, esa autorización para el tunecino de origen se limita únicamente al nombre y no se extiende al apellido, que se autoriza tan sólo al recién nacionalizado. El problema persiste entre los conversos, quienes, temiendo legítimamente un posible repudio por su comunidad de origen y la repulsa de la nueva comunidad, carecen de la posibilidad de cambiar los apellidos como una forma de normalización social, para poder vivir homogéneamente dentro de la sociedad sin una distinción que les ponga de relieve. ${ }^{17}$

\section{EL ORIGEN DE LA CALAMIDAD}

El origen no se remonta al antiguo sistema colonial otomano, aunque éste también mantenía una sociedad estamental de rasgo ideológico. Los súbditos del imperio eran musulmanes o vasallos ${ }^{18}$ de otras religiones que gozaban de la misma protección imperial siempre que mantuvieran su lealtad al emperador otomano. Aquella situación cambió con las reformas imperiales de finales del siglo XIX que comenzaron a fomentar la noción del Estado nación en el imperio otomano. Así, por decreto imperial del 19 de enero de 1869 se aprueba el Estatuto de la Ciudadanía Imperial, en virtud de ius sanginuis para los otomanos y otorgar el ius soli a los vasallos sin perjuicio de la ideología, religión o la pertenencia étnica, acabando así con cualquier otro precepto de vasallaje anterior. ${ }^{19}$

17 La actual normativa civil en España se ciñe en la misma línea de limitar el derecho a la alteración de nombre y apellidos. En cuanto al apellido, el artículo 205 del Reglamento del Registro Civil (Decreto 14 de noviembre de 1958) ofrece apenas tres supuestos cerrados y restringidos para el cambio, aunque en tales supuestos el art. 208 se refiere a graves inconvenientes, incluida la deshonra. No obstante, este cambio no se refiere a la conversión lingüística de apellidos extranjeros nacionalizados, que de alguna manera debería incluirse para impulsar la integración social, al mismo efecto que la conversión religiosa.

18 Los orientalistas estudiosos de la materia optaron por un uso transliterario, del término árabe [ئن como Dhimmí, sin ofrecerle una traducción concreta. A mi entender, éste se refiere concreta y exactamente al vasallaje del antiguo régimen, sin necesidad de dar más rodeos, y ambigüedad antonomásica.

19 La intencionalidad de la universalidad de la ciudadanía imperial se debía inicialmente a las reformas emprendidas por el Emperador Abdul-Mejid I (1823-1861) desde 
Parece que esa homogenización no agradó al colonialismo europeo, que rápidamente intervino en el imperio otomano bajo el pretexto de la protección de las minorías, de las identidades nacionales y de los cristianos. ${ }^{20}$ Así, una vez descolonizados los Estados, normativamente se impuso la fragmentación de las etnias, las fracciones y las identidades sociales de toda índole. Es decir, mediante los propios tratados de independencia, hicieron reservas que garanticen el derecho de las minorías, que en realidad no fueron otras que semilla de fragmentación, fisuras y segregación. Los incipientes Estados amanecieron acorralados, errantes entre su pertenencia nacional violada por el colonialismo durante los siglos precedentes mediante la instrumentalización religiosa, como postulado colonial y su nueva identidad condenada a una servidumbre impuesta por otro colonizador europeo, en los tratados de independencia, pero también con eje religioso. Este acorralamiento fue el principal motivo de repulsa de los movimientos del forjamiento nacional árabe durante las primeras décadas

su coronación en 1839 se empeñó en integrar los no musulmanes con los musulmanes bajo el lema de una ciudadanía e identidad nacional única en plena igualdad jurídica a todos los efectos, asegurando en primer nivel la igualdad entre cristianos y musulmanes, ya que formaban la absoluta mayoría de la población (Edib 1930, 68). Sin embargo, los cristianos se revesaron la obligación de prestar el servicio militar, gozando, por tanto, de absoluta libertad de integración comunitaria que les resulto más ventajosa en comparación con los demás. Pues por las circunstancias geopolíticas el imperio, las guerras eran incesantes, y el resto de los ciudadanos otomanos tenían su vid condena a la servidumbre militar; oportunidad que permitió a los cristianos mejor formación, estabilidad económica y social que les aventajó significativamente de los demás, en cambio se les prohibía portar armas, además de se infravaloraba su testimonio, en juicio, en caso de contradicción con el de otro testigo musulmán, sobre-valorando el honor de palabra del musulmán por considerarle combatiente imperial gazi. Este último criterio fue el que más les irritaba, siendo el arma de occidente alegando la discriminación de los cristianos, y la necesidad de su protección propiciando su alineación con occidente. Este hecho irritaba, al mismo tiempo, a los musulmanes, cuya vida estaba condenada eternamente a servir en los ejercito imperiales enredados en continuas guerras contra occidente, defensor de los cristianos, y quienes gozaban de estable y acomodada vida acumulando riquezas y prosperidad a costa de los demás (Edib 1930, 68 y 69); es decir, las reformas que se proyectaban para integrar y otorgar derechos, acabaron produciendo más resentimiento, fisuras y fragmentación por las reivindicaciones patriarcales y la interferencia extranjera.

20 Sin lugar a duda, también el colonialismo otomano, en su nueva regulación tuvo otra intención, que fue la de resolver el estamento identitario de los armenios, contra quienes desarrolló políticas de exterminio étnico. Esa cuestión se sale del objeto del presente artículo, pero es menester abordarla como otra posible finalidad de la nueva regulación de la identidad colonial otomana. 
del siglo XX empeñado primero en expulsar la religión del mix identitario, centrifugándose en otros valores de pertenencia como la lengua, o el imaginario histórico para la asimilación patriótica. ${ }^{21}$

\section{EL PAPEL DEL COLONIALISMO EUROPEO EN LA FRAGMENTACIÓN DE LAS IDENTIDADES SOCIALES}

Desde la invasión napoleónica de Egipto, su principal consecuencia fue la segregación social. Bajo el mandato de Napoleón se formó el primer tribunal mixto en Egipto. Al frente del mismo colocó a 12 jueces mixtos: seis musulmanes y otros seis coptos. A pesar de que los coptos apenas representaban el 10\% del tejido social en ese órgano jurisdiccional, Napoleón les asignó la mitad de la representación, dejando fuera a los judíos y a las demás confesiones no monoteístas, como los bahaítas. ${ }^{22} \mathrm{Y}$ para colmo en la presidencia colocó a un copto. ${ }^{23}$ A ese tribunal se le confirieron muchas competencias en detrimento de la jurisdicción preexistente. Primero se le otorgó competencia mercantil con el pretexto de agilizar el comercio. Un año más tarde se le confirió la segunda instancia de la jurisdicción común, es decir, terminó ejerciendo funciones casacionales sobre todas los demás órdenes (Sạlm 1986).

Además de ello, la época napoleónica impulsó la creación de jurisdicciones para las demás etnias de Egipto (distintas de las de musulmanes y copto-ortodoxas) como respuesta a la necesidad de restar parte de las competencias a los tribunales previamente existentes, que también sufrieron esa maniobra, cambiando la forma de elecciones de sus titulares. En lugar de ser nombrados por el emperador otomano pasaron a ser elegidos

21 Tomo prestada la acepción del forjamiento patriótico de Gamio el considerado padre del ideal nacionalista mexicano (Gamio 1982).

22 Hasta el día de hoy, los bahaítas no cuentan ni siquiera con identidad civil en Egipto.

23 En correspondencia interna de Napoleón con uno de sus generales, el general Keleber, el 28 de agosto 1798, le confiesa que: 'Quant à l'administration de la justice, c'est une affaire très-embrouillée chez les musulmans; il faut encore attendre que nous soyons un peu plus mêlés avec eux; laissez le divan faire à peu près ce qu'il veut”. Sin embargo, parece que la divina providencia le guio a que unos días después instaurará un tribunal en forma de Caballo de Troya que acabará globalmente con el sistema judicial egipcio y sembrara la fragmentación sectaria de la justicia (Napoléon Ier 1858, 73). 
por el pueblo de entre los eruditos de mayor reputación. De esta manera se trivializó la jurisdicción, pasando de ser jurisconsultos a ser legos popular y carismáticamente electos bajo el pretexto de su democratización. Desde entonces, y sin necesidad de adentrarnos en las particularidades, al igual que en Iraq, comenzaron a emergerse tribunales religiosos arbitrarios, es decir, tribales como recursos populares en detrimento, no sólo de la titularidad estatal, sino de la integración social, propiciando así la segregación sectaria bajo el pretexto general de la defensa de las minorías. Sociedades que convivían integradas, como un gazpacho, de pronto, una vez llegado el orientalismo colonial, acabaron siendo fragmentadas, definidas e identificadas como una ensalada mediterránea (Lamo de Espinosa 2007). Una quiebra de la razón, devolviendo al roble a su estado salvaje de bellota (Berlin 2017, 20).

Paradójicamente, todo esto era lo contrario de lo que pasaba en Europa. En Francia, concretamente, los tribunales metropolitanos franceses ya suprimieron, desde 1846, toda particularidad religioso-subjetiva en los procesos civiles y penales (CCF Cerf c. Gougendheim 1846) Entonces la Corte de Casación francesa se enfrentó a la cuestión del juramento More Fudaico, el cual requería que una persona de confesión judía gozaba de reservar para no jurar ni pronunciarse sobre la Torah, sino dentro de un templo consagrado al efecto, y en presencia de un rabino, hecho que dificultaba por una parte el procesamiento judicial, además suponía una involucración de los tribunales civiles con instituciones extrajudiciales. La casación francesa en este caso asentó la extirpación de los vínculos ideológicos-étnicos de los litigantes en proceso estableciendo la igualdad de todos los cuidadnos ante la Ley en todos los aspectos y esquemas procesales. Al mismo efecto en la (CGF Mohamed-Amokran-Oukaci 1882), la Corte volvió a enfrentarse con un caso paradójico. Procedía de una casación de la corte de Argel (cuando ésta era colonia francesa). Para entonces un ciudadano argelino, habitante de su propio país colonizado por la administración francesa impugnó el artículo 312 del Código de Instrucción Criminal, vigente entonces, en cuanto al pronunciamiento genérico del juramento en forma "juro", que a su parecer violaba su identidad religiosa al no concretar el objetivo del juramento. La Corte concluyó entonces que el juramento es un todo indivisible, sin reservas, enmiendas ni alteraciones en su fórmula que supondría su nulidad, no siendo objeto de alineación subjetiva. Es decir, cuando Europa se encaminaba hacía una 
sociedad humanista y de individuos asociados, los mismos poderes coloniales se empeñaron en desvertebrar las demás sociedades, convirtiéndolas en colectivos disociados y estratificados en un laberinto de minorías y derechos sectoriales y sectarios, punzantes, punzantes.

En Europa se rechazó la estratificación social basada en pertenencias étnicas o religiosas, al considerarla estéril e improductiva para el progreso social por su origen y su función. Por su origen, porque se trata de estructuras vicarias, ajenas al tejido social propio, procedentes de la sumisión o lo que García Pelayo llamó superposición y dominio de la colectividad social común a un poder ajeno a su cohesión propia. La identidad religiosa sólo sirve a los objetivos de su razón de ser, ajenos a la identidad social y colectiva. Una estratificación religiosa sirve únicamente a su ideología mística, una segregación étnica sirve a los intereses propios de la identidad étnica y, además, impide la cohesión de ésta en la ontología nacional (García Pelayo 1981, 61 y ss.). En cambio, en las colonias fueron los europeos quienes sembraron exactamente lo contrario. Mediante sus paquetes de prosperidad al portador, se auto-complacieron con sus fantasías, se encapricharon en imponer valores e instituciones que no sirvieron para otra cosa que alentar la xenofobia racial y el sectarismo social, y motivaran falsas adherencias a agresivos movimientos populistas que se empeñaron en movilizar a las masas sin otro objetivo que alentar el rencor contra el colonizador, un objetivo se agotó nada más lograr la independencia, cuyo día después amaneció impregnado de ansiosa búsqueda de nuevos valores para su nueva identidad, además condenada a adherirse a nuevos derechos punzantes impuestos por el colonizador. Es decir, el amanecer postcolonial árabe no fue otro que un drama de libertad errante entre unos derechos de identidad religiosa gestionados por poderosas oligarquías emergentes del colonialismo, y un idealismo melancólico de un espejismo del pasado.

En Iraq la situación no fue distinta. El protectorado británico, antes de otorgar la independencia, se aseguró de sembrar la asimetría jurídica y la segregación identitaria como encargo impuesto al futuro gobierno. Ello a pesar de que la ley fundamental del incipiente Estado iraquí de 1925 era de carácter aconfesional. Los artículos 73-75 ya sembraron la asimetría de los fueros jurisdiccionales islámico, evangélico y hebraico, que nunca habían existido como tales anteriormente. En virtud de ello se cristalizaron las jurisdicciones confesionales, primero por la Ley 78/1931, que creaba los tribunales de jurisdicción secular, civil y de familia, a los que se asig- 
naron todas las competencias civiles y de familia, salvo las reservadas al ámbito constitucional y de orden público que afecten a derechos individuales. Desde entonces estigmatizaron la imbricación jurídica del ámbito personal, reservado a los tribunales confesionales, y el ámbito público, conferido a los tribunales penales y administrativos del Estado. Se impuso así una bicefalia conceptual entre el futuro Estado nacional, su derecho y acepciones políticas, por un lado, y la pertenencia religiosa, étnica e identitaria por otro.

La bicefalia fue rechazada por las propias comunidades y minorías a las que las fuerzas coloniales decían querer proteger, instrumentalizándolas con meros fines coloniales. Un cuarto de siglo tuvo que transcurrir para que los judíos aceptasen codificar sus normas en el Estatuto Personal de la familia judía por la ley del 31 de diciembre de 1949. La fundación del Estado de Israel en 1948 fue uno de los motivos que movilizó a los judíos iraquíes para acceder a dicha codificación, ya que en cierta medida se resistían a emigrar a Israel y aceptaron dicha codificación bajo presión política. Con las comunidades eclesiales no fue tampoco fácil ni se logró el objetivo. Los caldeos (cristiano-ortodoxos) se negaron a prestar sus enseñanzas y a que fuesen investidas y codificadas por el legislador civil, al considerar "el proceso codificador como una intromisión en su independencia, por lo que puede suponer someter sus normas canónicas al legislador positivo, quien puede interferir de algún modo en la forma de aplicarlas, entrando en una pugna entre la iglesia y el Estado". ${ }^{24}$ En cambio, los asirios (católicos-orientales) sí dieron ese paso tras largas negociaciones que llevaron a la ordenación de su situación jurídica, tanto como los judíos, codificando sus ordenanzas canónicas en la ley del 6 de julio de 1950, gaceta oficial núm. 2855 (Albazzaz 1958, 118).

Los musulmanes, por su parte, no culminaron su Estatuto Personal hasta 1959, es decir, en tiempos de la república nacida en 1958, siendo éste precisamente uno de los motivos de este proceso, el oponerse a su segregación sectaria. El largo proceso codificador del Estatuto Personal islámico se debió a la intención de diseccionarles en dos grupos o cuerpos legales, una cuestión que no se zanjó hasta la derrota de la monarquía y

24 Según sus alegaciones registradas en el Ministerio de Justicia iraquí, recogidas en el registro de actas del proyecto de ley del 1949, citado por quien fue ministro de justicia iraquí (Albazzaz 1958, 117, nota 3). 
la instauración de la república. Ésta se alzó con el afán de impulsar una identidad nacional única y culminó, por tanto, el proceso mediante la promulgación de un solo y único estatuto de familia, la Ley 188/1969 personal aplicable a todos los musulmanes en Iraq sin segregación; es decir, lo que realmente impuso el colonialismo como protección de derechos identitarios no obtuvo la benevolencia ni fue abrazado por sus destinatarios, que rechazaban ser identificados como tales. Así siguió la situación hasta la llegada de la invasión americana que, con su pretexto clásico de defender las identidades culturales y minoritarias, impuso la segregación entre suníes y chíées. La primera decisión del gobierno transitorio de 2004 fue la de derogar el estatuto iraquí de la familia, alegando que no representaba a las minorías religiosas, que reclamaban la imposición de sus propias ideologías. Esto se hizo mediante el decreto 137/2004 del 29 de diciembre, que contenía apenas tres artículos que rezaban así:

Artículo primero: imponer las normas de la jurisprudencia islámica sobre todo lo relacionado con el matrimonio, la promesa matrimonial, la capacidad matrimonial, su prueba, el matrimonio mixto, los derechos matrimoniales y sus obligaciones, además de la nulidad, la separación y el divorcio y las demás cuestiones referentes a la custodia, manutención, el testamento, el legado y la herencia, sometidas todas a la jurisdicción de los tribunales seculares en virtud de cada escuela religiosa.

Artículo segundo: Se derogan todas otras leyes, reglamentos y demás disposiciones referentes a toda materia mencionada en el artículo anterior.

Artículo tercero: la presente ley entrara en vigor a la vista el presente.

Esto en plena ocupación, recién derrotado el Estado y en proceso de desmantelamiento de las instituciones, como si no hubiese otro asunto más importante del que ocuparse. Esta decisión fue motivo de gran repulsa social, por lo que rápidamente intervino la autoridad colonial, que la anuló para impedir la disidencia social en un momento considerado crítico. Precisamente los americanos, asesorados por sus orientalistas, lo impulsaron pensando que este gesto amistoso atraería a la población, pero la repulsa social les hizo entender rápidamente que no era así. Sin embargo, a pesar de retirar la ley, la estrategia sectaria siguió su camino en los posteriores procesos constitucionales. Volvieron a imponerla intencionadamente a propuesta del embajador americano en el impreciso artículo 41 de la rubricada Constitución de Iraq, de 2005, cuando declaró que "los iraquíes 
son libres de mantener su estatus personal según su religión, creencia, ideología u opción. La ley lo regulará”. Cabe destacar, finalmente, que existía otro cuerpo legal, el Estatuto Personal Civil, Ley 78/1931, designado como norma predeterminada aplicable a todos aquellos no afectados por las normas segregacionistas, es decir, a los que no contaban con una codificación: las demás ideologías y ritos, los agnósticos o voluntariamente ateos.

El problema nace de ahí precisamente. La segregación conllevó la determinación del fuero civil mediante la declaración del asiento registral para que, en virtud suya, abarcase la correspondiente competencia jurisdiccional y sirviese de instrumento de identificación. Esa instrumentalización excluyó a todos los efectos a todo agnóstico o a quien se opusiese a confesar una ideología concreta, ya fuese monoteísta o pagana. Por un lado, no tendría derecho a modificar su filiación registral, ni siquiera a optar por la jurisdicción civil si la contraparte no se sometiera a ésta, ya que se designaban por defecto los tribunales seculares como jurisdicción predeterminada por la ley con circunscripción subjetiva sobre todo aquel en cuya cédula de identidad figurase la filiación ideológica referida por la jurisdicción.

Un caso comparado al que podemos aludir es la sentencia del Tribunal Supremo del Estado de Israel, en el caso de Backer vs. Eilat (172/78), entonces un testigo de un caso de homicidio se negó a jurar sobre la Torah ante un tribunal penal alegando ser ateo. El tribunal entonces le negó tal objeción basada en la libertad de conciencia, considerando que no tenía acomodo dentro de la libertad de creencia por entender que ésta consiste en optar libremente por una creencia reconocible. Pero no siendo el ateísmo una religión como tal, sino se encuadraría dentro de la libertad de conciencia que es distinta de la libertad religiosa, el ateísmo sería una filosofía subjetiva, no una religión amparada por la libertad religiosa. Por tanto, y según el mandato de la Torah, el testigo ha de jurar respetar el buen y cierto testimonio ante el tribunal. Dicho incidente dio lugar a que el legislador israelí tomará la inmediata medida de suprimir el juramento ante los tribunales por la Ley 5740/1980, evitando así la controversia; es decir, evitó el problema sin resolverlo (Sinclair 1996, 410 y 411). 


\section{EPÍlOGO}

El colonialismo operó siempre bajo dirección de unos asesores que en muchos casos eran apenas filólogos, los llamados orientalistas, ajenos a oriente y a las disciplinas por las que hablaban. ${ }^{25}$ Esto desde Sacy y la escuela francesa feunes de Langues hasta la actualidad. Conocer el oriente nunca fue una cuestión románica ni científica, sino todo lo contrario. Era la carrera colonial a la que se refirió Said en palabras de Disraeli (Said 2003). Diseñaban estrategias, postulaban, hacían y deshacían no sólo en contra de los pueblos, sus culturas y cogniciones, sino también en contra de las categorías y conceptos con las que actuaban en su propia casa. Esa contradicción o paradoja no es un caso aislado ni una casualidad. Es la práctica despótica del colonialismo de convertir a pueblos y naciones en su conejillo de indias. Lo que los aliados americanos hicieron en Iraq con la Constitución de 2005 sería cabalmente incomprensible, inconstitucional e inconcebible en sus propios países. En los Estados Unidos de América no existen los derechos políticos de las minorías ni se reconoce la representación parlamentaria por cuotas de pertenencia religiosa, ni se reparten las carteras de la administración según las fracciones étnicas o confesionales. Sin embargo, en Iraq aplicaron todo eso. No fueron a llevar

25 Insisto en llamarles orientalistas, tal y como debe ser, aunque ese adjetivo desde la aparición de la polémica obra de Said en 1978 lo dotó de dimensión negativa. El orientalista es el ignorante de oriente quien apenas ni sabe ubicarlo geográficamente, ni había pesado en su vida tierras orientales, como un químico de aulas ajeno al laboratorio. Cierto que el lenguaje brindó términos cambiantes, pues desde la reivindicación de Said, los orientalistas se negaron esa rúbrica negativa acogiéndose a nuevas denominaciones, desde antropólogos, hasta recientemente en las décadas de los noventa expertos en terrorismo, antiradicalización, para que ahora pasen a autoproclamarse geoestratégas. Interesante y muy breve la reflexión que hizo Jasso Huezo sobre el ambiguo uso de ese concepto mediáticamente (Jasso Huezo 2020). En efecto, John Nixon, el principal analista de la CIA encargado del caso del presidente Iraquí Sadam Husein, antropólogo de formación, y autor del famoso libro de confesiones Debriefing the President (Nixon 2017), quien fue el primer y más extenso inspector de la CIA quien se entrevistó con el entonces preso Sadam Husein, en una entrevista televisiva con la cadena Alaraby al ser preguntado sobre su impresión al conocer a Sadam Husein en persona, dijo "me sentí totalmente defraudado por toda la literatura y la formación que me dieron en occidente, tuve que retirarme de las sesiones, regresar a Estados Unidos un mes para despejarme e intentar olvidarme de todo mi bagaje formativo y regresar nuevamente a conocer una realidad totalmente ajena a lo que domina nuestros relatos" (Nixon 2020).

Esta obra está bajo una Licencia Creative Commons

Atribución-NoComercial-SinDerivar 4.0 Internacional, IIJ-UNAM.

Boletín Mexicano de Derecho Comparado, núm. 158, mayo-agosto de 2020, pp. 485-519. 
su propia democracia, como anunciaron, sino todo lo contrario: llevaron una ideología diseñada por los becarios de sus asesores orientalistas, unos aprendices ajenos a toda realidad y prospección que se basaban en fantasías de la escuela orientalista. Una estrategia colonial diseñada por un orientalismo radicalmente ficticio (Said 2003, 13), destructivo, más nocivo que el despotismo ilustrado: "una fantasía vana, no un logro intelectual” (Berlin 2017, 23). La única conclusión empírica que se puede obtener es que Westfalia no sirvió para imponer la paz como tal frente a las guerras de religión, sino más bien para cambiar el argumento. En lugar de guerras de religión, ofreció la semántica para que fuesen guerras por la paz: por la paz de las minorías, por la paz industrial, por la paz de los intereses despóticos, o más bien, una paz hegemónica.

La conclusión que se deduce de todo esto es que el paradigma actual por el que se rige la academia occidental hacía el mundo árabe no sólo es perjudicial, sino que su nocividad ha alcanzado grados de criminalidad que deben seriamente repensarse. Es desde esta perspectiva empírica como hay que entender el rencor y la confrontación que se arrastra de generación en generación y que hoy han terminado llamándola terrorismo. No es otra que la cosecha de lo que se lleva sembrando desde hace décadas, o siglos. ¿A quién se debe el fruto de la cosecha? ¿A quien siembra en servidumbre o al dueño de la tierra?

\section{BibliografíA}

ALARABIYA. 2008. Shqvq wfạ qstntyn: «hy bkhyr» wmstshar alknyst almsryt ả ảblgh alnyabï.Alarabiya.https://wrewealarabiya.net/articles/2008/08/26/55501. html.

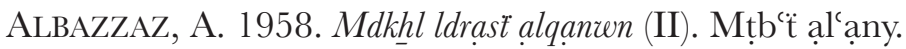

ALjAZERA. 2004. Asabt al'shrat fy mzahrt llạqbat balqahrt. Aljazera. https:// wwrealjazeera.net/news/miscellaneous/2004/12/12/\%D8\%A5\%D8\% B5\%D8\%A7\%D8\%A8\%D8\%A9-\%D8\%A7\%D9\%84\%D8\%B9\% D8\%B4\%D8\%B1\%D8\%A7\%D8\%AA-D9\%81\%D9\%8A-\%D9\%85 $\% D 8 \% B 8 \% D 8 \% A 7 D 9 \% 87 \% D 8 \% B 1 \% D 8 \% A 9-\% D 9 \% 84 \%$ D9\%84\%D8\%A3\%D9\%82\%D8\%A8\%D8\%A7\%D8\%B7.

ALJAZERA. 2015. Wfà' qstntyn wkamylya shhatt twdan llwajht. Aljazera. https://wwwaljazeera.net/news/reportsandinterviews/2015/2/16/\%D9\% 
88\%D9\%81\%D8\%A7\%D8\%A1-\%D9\%82\%D8\%B3\%D8\% B 7\%D $9 \% 86 \% D 8 \% B 7 \% D 9 \% 8 A \% D 9 \% 86-\% D 9 \% 88 \% D$ $9 \% 83 \% D 8 \% A 7 \% D 9 \% 85 \% D 9 \% 8 A \% D 9 \% 84 \% D 9 \% 8 A \% D 8 \% A$ 7-\%D8\%B4\%D8\%AD\%D8\%A7\%D8\%AA\%D8\%A9-\%D8\%AA\%D8\%B9\%D9\%88\%D8\%AF\%D8\%A7\%D9\%86.

AlNaSIR, S. 2019. Concepto jurídico, religión y secularidad: los casos de Israel, Egipto e Iraq. Universidad Carlos III de Madrid.

AlNaSIR, S. 2020. Ceremonial nupcial y protocolo matrimonial en el mundo árabeislámico. https://wrere.protocolo.org/social/bodas/ceremonial-nupcial-y-protoco lo-matrimonial-en-el-mundo-arabe-islamico-i.html.

ẠL'WẠ, M. S., \& Mnșwr, ạhḥmd. 2010. Atham alknyst alqbtyt baltghwwl qy aldwlt walqanw. Aljazeera. https://wwrealjazeera.net/programs/without bounds $12010 / 9 / 23 / \% D 8 \% A 7 \% D 8 \% A A \% D 9 \% 8 \% D 8 \% A 7 \% D 9 \% 85$ - \%D8\%A7\%D9\%84\%D9\%83\%D9\%86\%D9\%8A\%D8\%B3\%D8\% A9-\%D8\%A7\%D9\%84\%D9\%82\%D8\%A8\%D8\%B7\%D9\%8A\%D8\% A9-\%D8\%A8\%D8\%A7\%D9\%84\%D8\%AA\%D8\%BA\%D9\%88\%D9\% $84-\% D 8 \% B 9 \% D 9 \% 84 \% D 9 \% 89$.

BAÑOS, P. 2017. Asi se domina el mundo. Espasa.

BERLIN, I. 2017. El sentido de la realidad: sobre las ideas y su historia. H. Hardy (ed). P. Cifuentes (trad.). Taurus.

Bruinessen, M. van. 2018. "The Governance of Islam in Two Secular Polities: Turkey's Diyanet and Indonesia's Ministry of Religious Affairs". European Fournal of Turkish Studies. Social Sciences on Contemporary Turkey, 27, Article 27. https://doi.org/10.4000/ejts.5964.

Galvo Caravaca, A. L. y Carrascosa González, J. 2005. "Derecho internacional privado y matrimonios entre personas del mismo sexo". Anales de Derecho de Murcia, 23: 11-70. https://revistas.um.es/analesderecho/ article/view/56411.

CCF Cerf c. Gougendheim (Cour de Cassation Française 8 de marzo de 1846). https://play.google.com/books/reader?id $=D H o$ Nyj3 qS54CËpg $=G B S$. PA1.

CGF Mohamed-Amokran-Oukaci (Coure de Casation Française 20 de mayo de 1882). https://gallica.bnfffr/ark:/12148/bpt6k5580135z/ f999n993.texteBrut.

Cebrián SAlvat, M. A. 2017. "Ley aplicable a la celebración del matrimonio en la Unión Europea". InDret Privado Revista para el Análisis del

Esta obra está bajo una Licencia Creative Commons

Atribución-NoComercial-SinDerivar 4.0 Internacional, IIJ-UNAM.

Boletín Mexicano de Derecho Comparado, núm. 158, mayo-agosto de 2020, pp. 485-519. 
Derecho, 4. https://indret.com/ley-aplicable-a-la-celebracion-del-matrimonio-enla-union-europea/?edicion $=4.17$.

CraWford, N. 2018. Costs of War: Iraqi Civilians. Waston Institue of International Affairs. https://watson.brown.edu/costsofwar/costs/human/civilians/ iraqi.

EDIB, H. 1930. Turkey Faces West. Yale University Press. https://ia902700. us.archive.org/30/items/turkeyfaceswesta010382mbp/turkeyfaceswest a010382mbp.pdf.

Gamio, M. 1982. Forjando patria. F. Armstrong-Fumero (trad.). Porrúa.

García Pelayo, M. 1981. El tema de las nacionalidades: la teoría de la nación en Otto Bauer. Editorial Pablo Iglesias.

GARZÓN VALDÉS, E. 2004. Calamidades: la responsabilidad humana ante la atrocidad. Gedisa.

GÉNY, F. 2007. La libertad en derecho: entre certeza e incertidumbre. M. J. Bernuz Beneitez (trad.). Comares.

Grossi, P. 2007. Europa y el derecho. L. Giuliani (trad.). Editorial Crítica.

Hagopian, A. et al. 2013. "Mortality in Iraq Associated with the 20032011. War and Occupation: Findings from a National Cluster Sample Survey by the University Collaborative Iraq Mortality Study". PLOS Medicine, 10(10), e1001533. https://doi.org/10.1371/journal.pmed.1001533.

JASsO Huezo, R. 2020. "Sobre la palabra geopolítica". El Universal. https://wrere.eluniversal.com.mx/opinion/ricardo-jasso-huezo/sobre-la-palabrageopolitica.

LAMO de Espinosa, E. 2007. "La globalización cultural. ¿Crisol, ensalada o gazpacho civilizatorio?’”. Almaraz Pestana, J. y Carabaña, J. (eds.). Lo que hacen los sociólogos: Homenaje a Carlos Moya Valgañón. Centro de Investigaciones Sociológicas, 543-575.

LEY20/1964.http://wwrw.legislation.tn/sites/default/files/journal-officiel/1964 /1964A/fa02764.pdf.

Luhmann, N. 1977. Funktion der religion. Suhrkamp.

Luhmann, N. 1985. "Society, Meaning, Religion: Based on SelfReference". Sociological Analysis, 46(1), 5-20. JSTOR. https://doi. org/10.2307/3710892.

Middle East online. 2004. Qbtyt tthyr åzmit fy msr bsbb aslamha [Regional press]. Middle East online. https://middle-east-online.com/\%D9\%82\%D8\%A8\% D8\%B7\%D9\%8A\%D8\%A9-\%D8\%AA\%D8\%AB\%D9\%8A\%D8\%B1\%D8\%A3\%D8\%B2\%D9\%85\%D8\%A9-\%D9\%81\%D9\%8A-\%D 
9\%85\%D8\%B5\%D8\%B1-\%D8\%A8\%D8\%B3\%D8\%A8\%D8\%A8$\% D 8 \% A 7 \% D 8 \% B 3 \% D 9 \% 84 \% D 8 \% A 7 \% D 9 \% 85 \% D 9 \% 87 \% D 8 \% A 7$.

Minorities and the Law in Iraq. 2011. Institute for International Law and Human Rights. http://iilhr.org/indexarreport.html.

Moreno Fernández, F. 2009. Principios de sociolinguística y sociología del lenguaje. 4a. ed. Ariel.

NAPOLÉON Ier. 1858, 1869. Correspondance de Napoléon Ier. Tome 4. Publiée par ordre de l'Empereur Napoléon III. https://galli ca.bnf.fr/ark:/12148/bpt6k9636650x/f404.item?fbclid=IwAROn MBh-V7G7h8OH8nkxx7fxrt8wF1bhVEJe9ElImz3e9hH68okSgYmyqjE.

NIXON, J. 2017. Debriefing the President: The Interrogation of Saddam Hussein. Penguin Random House.

NIXON, J. 2020. Asrar myl «sy ây ảy» aldhy lahq șdam hsyn lsnwat [Alaraby TV]. https://youtu.be/gj88mLDjfmE.

ORTEGA y GASSET, J. 1921. "España Invertebrada". Revista de Occidente.

RAWAF, S. 2013. "The 2003 Iraq War and Avoidable Death Toll". PLOS Medicine, 10(10), e1001532. https://doi.org/10.1371/journal. pmed.1001532.

Robin, C. 2004. Fear: The History of a Political Idea. Oxford University Press, USA.

SAID, W. E. 2003. Orientalism. Vintage Books.

SẠLM, L. mḥmd. 1986. Alnzam alqdaỷy almșry alhdyth (1914-1952), vol. II. Dạr ạlshruqu.

SINCLAIR, D. 1996. "Jewish Law in the State of Israel". Jackson, B. S. y Passamaneck, S. (eds.). An Introduction to the History and sources of Jewish Law, vol. 22. Oxford Clarendon Press. DOI:10.1093/acprof:o so/9780198262626.003.0015.

SMelser, N. 2013. Essays in Sociological Explanation. Quid Pro Books.

STAC 10838/58. Tribunal Administrativo de El Cairo. 24 de abril de 2007.

STC 11/1981. Recurso de inconstitucionalidad. Tribunal Constitucional Español. 8 de abril de 1981. https://hj.tribunalconstitucional.es/es-ES/Reso lucion/Show/11.

STC 24/1982. Recurso de inconstitucionalidad registrado con el núm. 68/1982. Tribunal Constitucional Español. 13 de mayo de 1982. https://hj.tribunalconstitucional.es/es/Resolucion/Show/66\#complete_ resolucion Ecompleta.

Esta obra está bajo una Licencia Creative Commons

Atribución-NoComercial-SinDerivar 4.0 Internacional, IIJ-UNAM.

Boletín Mexicano de Derecho Comparado, núm. 158, mayo-agosto de 2020, pp. 485-519. 
STC 58/82. Recurso de inconstitucionalidad núm. 572/91. Tribunal Constitucional Español. 30 de julio de 1998. Depuración del lenguaje legislativo. http://hj.tribunalconstitucional.es/es-ES/Resolucion/Show/3652.

STC 99/87. Recurso de inconstitucionalidad núm. 763/84. Tribunal Constitucional Español. 11 de junio de 1987. http://hj.tribunalconstitucional.es/ es-ES/Resolucion/Show/831.

STC 101/2004. Tribunal Constitucional Español 2004. http://hj.tribunal constitucional.es/es-ES/Resolucion/Show/5106.

STCEG 55/22. Tribunal Constitucional Egipcio. 4 de agosto de 2001. http://wwre.sccourt.gov.eg/SCC/faces/PortalHome.jspx?Adf-Window-Id=uzzlb09rx\&Adf-Page-Id=0.

STCI 1741/2008. Tribunal de Casación de Iraq. 25 de noviembre de 2008. https://wrwre.hjc.iq/quiew.948/.

WOJCIECHOWSKI, G. 2002. Las competencias patriarcales en el derecho canónico oriental: estudio histórico-canónico. Universidad de Navarra.

'RF̈̈, M.jmạl. 2010. Alknyst almsryt. Hl hy dwlt dakhl aldwlt! Islam Way. https: // ar.islamway.net/article/61 77/\%D8\%A7\%D9\%84\%D9\%83\%D9\% 86\%D9\%8A\%D8\%B3\%D8\%A9-\%D8\%A7\%D9\%84\%D9\%85\%D8\% B5\%D8\%B1\%D9\%8A\%D8\%A9-\%D9\%87\%D9\%84-\%D9\%87\% D9\%8A-\%D8\%AF\%D9\%8 8\%D9\%84\%D8\%A9-\%D8\%AF\% D8\%A7\%D8\%AE\%D9\%84-\%D8\%A7\%D9\%84\%D8\%AF\%D9\%88\% D9\%84\%D8\%A9. 